\title{
Reformulasi Kebijakan Penanggulangan Bencana di Indonesia
}

\author{
Osmar Shalih, Riant Nugroho \\ ${ }^{1}$ Badan Nasional Penanggulangan Bencana (BNPB), Indonesia \\ ${ }^{2}$ Rumah Reformasi Kebijakan (RRK), Indonesia
}

DOI: 10.32781/cakrawala.v15i2.379

\section{ARTICLE INFO}

Evaluasi,

Implementasi,

Reformulasi,

Kebijakan,

Sistem Penanggulangan Bencana.

\section{Article History:}

Received : 26 Juli 2021

Accepted : 4 Nov 2021

Publish : 22 Des 2021

\section{Abstrak:}

Tujuan penelitian ini merumuskan konsepsi reformulasi kebijakan pe-nanggulangan bencana di Indonesia khususnya dihadapkan pada tantangan meningkatnya tren bencana alam dan non alam seperti pandemi Covid-19. Penelitian ini menggunakan pendekatan kualitatif deskriptif dengan menekankan pada studi literatur guna mengkaji beberapa metode dan pengalaman (lesson learnt) di berbagai implementasi kebijakan penanggulangan bencana di Indonesia. Hasil penelitian adalah perlunya reformulasi kebijakan pada setiap fase kebencanaan (pra-bencana, tanggap darurat, pascabencana) dari berbagai aspek sistem penanggulangan bencana, yaitu legislasi-regulasi, perencanaan, kelembagaan dan pendanaan. Adapun reformulasi kebijakan penanggulangan bencana yang diusulkan adalah (1) melindungi segenap bangsa Indonesia dan seluruh tumpah darah Indonesia (dengan merefomulasi kebijakan pendanaan yang memadai untuk setiap tahapan penanggulangan bencana); (2) memajukan kesejahteraan umum (mereformulasi kebijakan pascabencana yang berprinsip build back better, safer and sustainable); (3) mencerdaskan kehidupan bangsa (mereformulasi kebijakan pengarusutamaan atau mainstreaming pengurangan risiko bencana ke seluruh lapisan masyarakat, melalui komunikasi, edukasi dan informasi); (4) ikut melaksanakan ketertiban dunia berdasarkan kemerdekaan, perdamaian abadi dan keadilan sosial (mereformulasi kebijakan melakukan kerjasama, baik dalam dan luar negeri untuk kebencanaan); dan ini telah sejalan dengan amanat konstitusi UUD 1945.
\end{abstract}

\section{Abstract:}

The purpose of this study is to formulate the concept of reformulation of disaster management policies in Indonesia, especially faced with the challenge of increasing trends in natural and non-natural disasters such as the Covid-19 pandemic. This study uses a descriptive qualitative approach with an emphasis on literature studies in order to examine several methods and experiences (lesson learned) in various implementations of disaster management policies in Indonesia. The result of the research is the need for policy reformulation in each phase of a disaster (predisaster, emergency response, post-disaster) from various aspects of the disaster management system, namely legislation, planning, institutions and funding. The proposed disaster management policy reformulations are (1) to protect the entire Indonesian nation and the entire homeland of Indonesia (by reformulating adequate funding policies for each stage of disaster management); (2) promoting public welfare (reforming post-disaster policies with the principle of build back better, safer and sustainable); (3) educating the nation's life (reformulating the policy of mainstreaming or mainstreaming disaster risk reduction to all levels of society, through communication, education and information); (4) participate in implementing world order based on freedom, eternal peace and social justice (reformulating policies for cooperation, both domestically and internationally for disasters); and this is in line with the constitutional mandate of the 1945 Constitution. 


\section{PENDAHULUAN}

Agenda janji Kemerdekaan yang pertama adalah "Melindungi segenap bangsa Indonesia dan seluruh tumpah darah Indonesia". Janji ini dituangkan dalam Undang-Undang Nomer 24 tahun 2007 tentang Penanggulangan Bencana. Jika melihat dari momentum waktunya, Indonesia relatif terlambat menyusun sebuah kerangka regulasi sistem penanggulangan bencana yang komprehensif. Jika melihat kondisi geografis negara Indonesia yang merupakan wilayah dengan ancaman bencana geologis maupun hidrometeorologis (Kristian, 2018), (Hayaturrahmi dan Husna, 2018), (Hartono dkk., 2021).

Kerangka regulasi tersebut berupaya merespon berbagai kejadian bencana di Indonesia dengan membangun suatu sistem penanggulangan bencana dari segi legislasi, kelembagaan, penyelenggaraan (pra, tanggap darurat, dan pascabencana), maupun pengganggaran (budgeting). Undang-Undang No. 24 Tahun 2007 tentang Penanggulangan Bencana ditetapkan bersama antara pemerintah dan DPR untuk membangun suatu sistem penanggulangan bencana yang tangguh di Indonesia. Selanjutnya ditetapkan aturan turunan antara lain berupa: Peraturan Pemerintah No. 21 Tahun 2008 tentang Penyelenggaraan Penanggulangan Bencana; Peraturan Pemerintah No. 22 Tahun 2008 tentang Pendanaan dan Pengelolaan Bantuan; Peraturan Pemerintah No. 23 Tahun 2008 tentang Peran Serta Lembaga Internasional dan Lembaga Asing Non Pemerintah dalam Penanggulangan Bencana. Dari segi kelembagaan, dibentuklah Badan Nasional Penanggulangan Bencana pada tahun 2008 yang memiliki fungsi pengkoordinasian pelaksanaan kegiataan penanggulangan bencana secara terencana, terpadu, dan menyeluruh dengan ditetapkannya Peraturan Pesiden No. 8 Tahun 2008 tentang Badan Nasional Penanggulangan Bencana.
Namun demikian, kerangka kebijakan tersebut masih memerlukan perbaikan. Terdapat beberapa isu yang dihadapi saat ini baik di Indonesia maupun di Dunia. Isu tersebut, yaitu tren bencana alam dan non-alam yang semakin meningkat dari waktu ke waktu dan belum dapat diprediksi secara tepat dan akurat, mengakibatkan tingginya dampak yang ditimbulkan dari setiap bencana yang terjadi, khususnya yang berskala masif hingga global seperti pandemi Covid-19. Bencana non-alam seperti Pandemi Covid-19 belum jelas kapan akan berakhir dan tentunya akan berdampak luas ke berbagai sektor dan mempengaruhi tujuan pembangunan nasional dan tentunya konstelasi global. Sampai dengan saat ini, Indonesia merupakan salah satu negara episentrum pandemi Covid-19 jika ditinjau dari jiwa terpapar (Hadi, 2020), (Shalih $d k k$, 2020), (Shalih, 2019), value orientation and risk preference(Hayaturrahmi dan Husna, 2018), (Hartono dkk, 2021), (Makmur dan Hadi, 2020), (Muhyiddin dan Hadi, 2020).

Penelitian ini menjadi penting dalam hal untuk mengkaji dan memahami proses perubahan kebijakan, dimana kebijakan berubah dari waktu ke waktu untuk mendapatkan wawasan yang lebih tentang bagaimana mengukur suatu peradaban bangsa. Momentum perubahan dan dinamika kebijakan, maka dapat dilihat juga apakah terjadi perubahan paradigma kebijakan. Dengan demikian, menyelidiki kompleksitas dan nuansa ide-ide kebijakan diharapkan dapat memberi kita jendela ke dalam masyarakat kita sendiri, bagaimana ia berupaya menyelesaikan masalah dan bagaimana solusi yang dihasilkannya (Hogan dan Howlett, 2015). Sejalan dengan hal tersebut, bahwa setiap kebijakan perlu dilakukan evaluasi untuk mereformulasi suatu kebijakan yang lebih baik (Kelly dan Booth, 2013).

Model kebijakan penanggulangan bencana sejak awal disusun memang tidak hanya menitikberatkan pada peran 
pemerintah. Hal ini sejalan dengan konsepkonsep seperti pemerintah telah beralih dari model perintah dan kontrol pemerintahan yang kolaboratif, interaktif dan model jaringan tata kelola yang kolaboratif (collaborative governance) (Craft dan Howlett, 2012).

Dengan memperhatikan latar belakang diatas, maka diperlukan suatu kebijakan penanggulangan bencana di Indonesia yang tangguh (resilience) dan handal ditengah tantangan tren ancaman bencana alam dan non alam yang meningkat dan dalam rangka menuju Indonesia Tangguh 2045 sesuai Rencana Induk Penanggulangan Bencana yang telah ditetapkan melalui Peraturan Presiden. Tujuan artikel ini untuk merumuskan konsepsi reformulasi kebijakan penanggulangan bencana di Indonesia.

\section{TINJAUAN PUSTAKA}

\section{Evaluasi dan Reformulasi Kebijakan}

Dalam konteks merumuskan kebijakan publik, Nugroho (2014) mengemukakan beberapa model yang dapat digunakan yaitu: model kelembagaan, model proses, model kelompok, model elit, model rasional, model inkremental, model permainan, model pilihan publik, model sistem, model demokratis, model strategis, dan model deliberatif (Nugroho, 2014), (Jachock, 2016). Pearson (2013) menambahkan dalam merumuskan kebijakan publik, setidaknya mencakup hal-hal sebagai berikut: identifikasi masalah kebijakan (identifying policy problems); merumuskan usulan kebijakan (formulating policy proposals); melegitimasi kebijakan publik (legitimizing public policy); Implementasi kebijakan public (implementing public policy); dan mengevaluasi kebijakan public (evaluating public policy) (Pearson, 2013).

Perumusan kebijakan publik merupakan "core" atau inti dari kebijakan publik itu sendiri, dimana dilakukan limitasi kebijakan yang pada tujuannya untuk mengintervensi kehidupan publik. Pada akhirnya, perumusan kebijakan merupakan usaha yang dilakukan pemerintah untuk melakukan intervensi terhadap permasalahan yang ada pada ranah publik. Dari segi proses, perumusan kebijakan terdiri dari beberapa tahapan, antara lain: (1) menetapkan masalah/isu baik saat ini maupun tantangan ke depan; (2) melakukan analisis kebijakan; dan (3) membuat keputusan.

Sementara evaluasi formulasi kebijakan publik yaitu berkaitan erat dengan apakah formulasi tersebut telah dilaksanakan: (1) menggunakan pendekatan yang sesuai dengan masalah yang hendak diselesaikan, (2) mengarah pada permasalahan inti, (3) mengikuti prosedur yang diterima secara optimal, dan (4) mendayagunakan sumber daya yang ada secara optimal. Salah satu teknik evaluasi kebijakan dapat mengacu pada muatan kebijakan itu relevan dengan masalah yang hendak dipecahkan dengan kriteria dasar yaitu adanya kesesuaian muatan dengan masalah, masalah strategis, dan tujuan yang hendak dicapai (Nugroho, 2015).

Dalam konteks proses reformulasi kebijakan publik, penting untuk melakukan perumusan masalah. William $\mathrm{N}$ dunn mengemukakan beberapa proses dalam perumusan masalah, antara lain: pencarian masalah (problem search); pendefinisian masalah (problem definition), spesifikasi masalah (problem specification), dan pengenalan masalah (problem sensing) (Dunn, 1994). Lebih jauh Patton dan Sawicki mengusulkan 7 (tujuh) tahapan dalam merumuskan masalah, antara lain: (1) Memikirikan suatu masalah; (2) Menggambarkan batasan/limitasi masalah; (3) Mengembangkan fakta; (4) Mengurutkan tujuan (goals) dan sasaran (objectives); (5) Mengidentifikasi ukuran 
masalah; (6) Menunjukan biaya dan keuntungan potensial; (7) Membahas pernyataan masalah (Patton dan Sawicki, 1993).

\section{Sistem Penanggulangan Bencana}

Sistem penanggulangan bencana dibangun berdasarkan kerangka dasar legislasi peraturan perundangan terkait Undang Undang No. 24 Tahun 2007 tentang Penanggulangan Bencana beserta turunannya (Peraturan Pemerintah, Peraturan Presiden, Peraturan Kepala BNPB, dan sebagainya) (Maarif, 2012). Ditinjau dari sifatnya, maka penanggulangan bencana juga harus bersifat menyeluruh (holistic). Artinya, penanganan bencana tidak bersifat parsial memperhatikan seluruh sendi kehidupan. Dalam kerangka kebijakan penanggulangan bencana tersebut, telah dijelaskan bahwa bencana merupakan urusan seluruh pihak (multi stakeholder). Dalam perkembangannya, bencana sebagai urusan seluruh pihak saat ini dikenal dengan model pendekatan pentahelix, yaitu akademisi melibatkan Pemerintah, Akademisi, Dunia Usaha, Masyarakat, dan Media.

Model pendekatan pentahelix ataupun multiplehelix, yaitu yang melibatkan Pemerintah, Akademisi, Dunia Usaha, Masyarakat, dan Media saat ini dinilai sangat tepat untuk mengakomodasi partisipasi seluruh pihak dengan mekanisme koordinasi dan kolaborasi (collaborative governance). Namun demikian, sebagaimana amanat peraturan perundangan dimaksud, tanggungjawab utama tetap bertumpu pada Pemerintah, baik pada level Pusat, Provinsi, Kabupaten/Kota hingga level Desa (heavy government). Dari segi pentahapannya, maka penyelenggaraan penanggulangan bencana dimulai dari tahap prabencana, tanggap darurat dan pascabencana.
Secara umum, sistem penanggulangan bencana merupakan suatu kerangka konseptual yang saling terintegrasi dengan beberapa aspek, yaitu: kerangka legislasi (regulation), perencanaan (planning), kelembagaan (institutional), pendanaan (budjeting), pengembangan kapasitas (capacity building) dan penyelenggaraan penanggulangan bencana (disaster management implementation) (Maarif, 2012). Sistem penanggulangan bencana yang tertuang dalam dalam Undang-Undang No. 24 Tahun 2007 tentang Sistem Penanggulangan Bencana sudah sepatutnya diterapkan diseluruh wilayah Indonesia mengingat Indonesia berisiko tinggi terhadap bencana (Kristian, 2018).

Walaupun sistem penanggulangan bencana secara nasional tersebut telah disusun pada dalam kerangka konseptual, namun implementasi sistem penanggulangan bencana juga sangat bersifat lokalitas. Masing-masing daerah memiliki kearifan lokal dalam penanggulangan bencana maupun mengelola risiko bencana yang dapat dilihat pada Gambar 1 (Maarif dkk., 2012). Berbagai lesson learnt di berbagai negara di benua Asia, Amerika, dan Afrika, menunjukan bahwa keberhasilan programprogram pengurangan risiko bencana berdasarkan partisipasi dan kontribusi komunitas. Komunitas lokal merupakan aktor utama dalam penanggulangan bencana. Pendekatan partisipatoris, keterampilan dan pengetahuan lokal (local wisdom) menjadi bagian dari sistem penanggulangan bencana yang tidak terpisahkan dan berperan besar dalam upaya pengurangan risiko bencana (Maarif, 2013). Sejalan dengan hal tersebut, dalam kerangka legislasi penanggulangan bencana, yaitu Undang-Undang Nomor 24 Tahun 2007 tentang Penanggulangan Bencana juga telah ditegaskan bahwa pentingnya peran 
serta masyarakat dalam penanggulangan bencana "bahwa setiap warga negara memiliki hak untuk berpartisipasi dalam pengambilan keputusan dalam penanggulangan bencana", dimana peran serta tersebut mencakup "pengambilan keputusan, memberikan informasi, pengawasan, perencanaan, implementasi, dan pemeliharaan program" (Hadi, 2020). Dengan aspek yang bersifat lokalitas, masing-masing individu diharapkan menjaga dan memelihara kelestarian alam. Upaya tersebut harus di lakukan oleh setiap individu dalam segala aktivitasnya untuk menjamin kualitas hidup manusia (kita jaga alam, alam jaga kita). Secara konseptual, hal ini sejalan dengan membangun upaya kedasaran terhadap bencana (Ambo dan Sulandari, 2008). Setiap perencanaan pembangunanan diharapkan memberikan keberpihakan (affirmative policy planning) pada keselarasan dengan alam. Perencanaan pembangunan berbasis pendekatan ekologis diharapkan mampu menjaga keseimbangan alam (Kodar, 2020).

\section{METODE PENELITIAN}

Penelitian ini menggunakan pendekatan kualitatif - deskriptif. Penelitian dengan pendekatan kualitatif bertujuan untuk menafsirkan suatu fenomena menafsirkan suatu fenomena untuk mencari suatu jawaban atas suatu rumusan masalah. Penelitian kualitatif bersifat mendalam, alamiah, dan menghasilkan atau "merekonstruksi" teori atau pengetahuan baru. Lebih jauh, penelitian kualitatif tidak diperoleh dari prosedur statistik, tetapi dengan melalui pengungkapan dan pemahaman terhadap sesuatu fenomena sosial yang belum diketahui dengan cara membangun gambaran yang holistik dan kompleks, diungkapkan dalam pernyataan, melaporkan secara detail pandangan dari informan dan dilakukan pada situasi yang alamiah (Strauss dan Corbin J, 2003), Creswell, 2013). Penelitian ini termasuk dalam penelitian evaluasi yang bersifat deskriptif. Dalam konteks penelitian ini, maka penekanan pada penggambaran dan pemahaman fenomena yang kompleks yang berpengaruh terhadap kebijakan penanggulangan bencana yang ada saat ini. Penulis juga melakukan eksplorasi secara mendalam terhadap program, kejadian proses serta aktivitas dalam pelaksanaan program, khususnya terkait penanggulangan bencana di Indonesia.

Data dan informasi diperoleh berdasarkan studi literatur sehingga diharapkan dapat saling menutupi

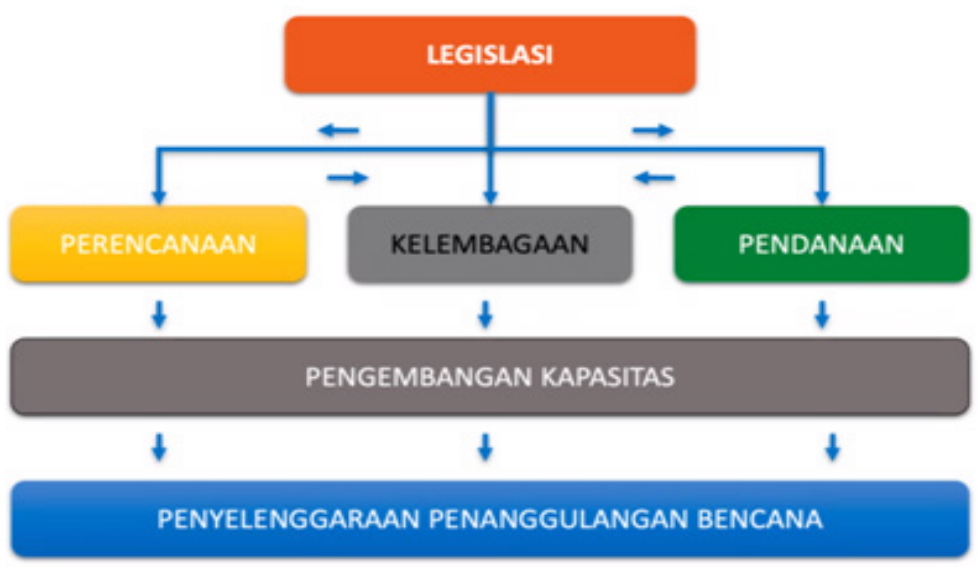

Sumber: Diadopsi dari Maarif (2012)

Gambar 1

Sistem Penanggulangan Bencana Indonesia 
kelemahan dan melengkapi data atau informasi yang dibutuhkan serta menangkap realitas masalah agar menjadi lebih diandalkan (triangulasi data dan informasi). Beberapa studi pustaka dilakukan guna mengkaji beberapa metode atau pengalaman di berbagai implementasi kebijakan penanggulangan bencana di Indonesia. Pengalaman tersebut digunakan sebagai lesson learnt kebijakan penanggulangan bencana di Indonesia. Teknik analisis data menggunakan pendekatan kualitatif deskriptif yang didesain berdasarkan kerangka konseptual sistem penanggulangan bencana di Indonesia, kemudian menghasilkan kesimpulan yang berguna untuk menjawab rumusan masalah dalam penelitian ini, yaitu berkaitan dengan reformulasi kebijakan penanggulangan bencana di Indonesia.

\section{HASIL DAN PEMBAHASAN}

Penanggulangan bencana meliputi tahapan prabencana, saat tanggap darurat, dan pascabencana. Berikut ulasan mengenai reformulasi kebijakan penanggulangan bencana pada masing-masing tahapan atau fase. Adapun secara ringkas dapat dilihat pada Lampiran 1.

\section{Reformulasi Kebijakan pada Tahap Prabencana}

Dalam UU 24 tahun 2007 tentang penanggulangan bencana, penyelenggaraan penanggulangan bencana dalam situasi tidak terjadi bencana antara lain meliputi: (1) perencanaan penanggulangan bencana; (2) pengurangan risiko bencana; (3) pencegahan; (4) pemaduan dalam perencanaan pembangunan; (5) persyaratan analisis risiko bencana; (6) penegakan rencana tata ruang; (7) pendidikan dan pelatihan; dan (8) persyaratan standar teknis penanggulangan bencana. Sementara dalam hal situasi situasi terdapat potensi terjadi bencana, maka penyelenggaraan penanggulangan bencana meliputi: (1) ke- siapsiagaan; (b) peringatan dini; dan (c) mitigasi bencana.

Berdasarkan evaluasi kebijakan pada tahap prabencana, legislasi atau regulasi yang ada belum seluruhnya regulasi yang disusun adaptif dengan upaya pengurangan risiko bencana (peka terhadap aspek kebencanaan). Berbagai studi mengemukakan bahwa aktifitas ekonomi seperti pertambangan tidak memperhatikan aspek risiko bencana (Wijayanto $d k k$., 2020). Pentingnya penerapan sanksi (disinsentif), maupun penghargaan (insentif) terhadap regulasi dan legislasi yang disusun (Luh dkk., 2021). Penulis juga mengusulkan perkuatan kebijakan pengarusutamaan (mainstreaming) pengurangan risiko bencana ke dalam legislasi atau regulasi yang disusun, utamanya terkait pembangunan di pusat dan daerah (RPJMN/D, RKP/D, RTR/ RTRW/RDTR, dan sebagainya).

Sementara untuk aspek perencanaan pada tahap prabencana, yaitu belum sepenuhnya perencanaan pembangunan di daerah memasukan aspek kebencanaan. Kajian Risiko Bencana (KRB) dan Rencana Penanggulangan Bencana (RPB) masih belum seluruh daerah memilikinya. Kedua dokumen tersebut utamanya digunakan sebagai dasar perencananaan sektoral. Hal ini juga sejalan dengan penelitian yang dilakukan oleh Sutrisna (2020) yang mengemukakan perencanaan sektoral kesehatan, belum memperhatikan aspek kebencanaan dikarenakan belum adanya kajian risiko bencana dan rencana penanggulangan bencana di daerah tersebut (Sutrisna, 2020). Usulan reformulasi kebijakan untuk aspek perencanaan pada tahap prabencana, yaitu perkuatan kebijakan pengarusutamaan (mainstreaming) pengurangan risiko bencana ke dalam rencana pembangunan di pusat hingga ke daerah. Rencana Penanggulangan Bencana (RPB) beserta 
perencanaan penanggulangan yang lebih detail dan Kajian Risiko Bencana (KRB) dijadikan dasar perencanaan sektoral lainnya.

Sementara untuk kelembagaan pada tahap prabencana, juga masih perlu perkuatan dalam pengurangan risiko bencana. Pengurangan risiko bencana harus menjadi pengarusutamaan (mainstreaming) dalam kehidupan sehari-hari. Seluruh lapisan masyarakat harus memahami konseptual maupun implementasinya dalam kehidupan (Cempaka $d k k$., 2021). Dalam hal upaya mitigasi untuk mengurangi risiko bencana yang kemungkinan terjadi dimasa yang akan datang, maka budaya hidup harmoni) dengan bencana (living harmony with disaster risk) harus ditanamkan kepada masyarakat melalui kearifan lokal yang ada di daerah. Langkah ini perlu dipersiapkan agar kerugian materi dan non-materi bisa diminimalkan (Hartono dkk., 2021), (Samad $d k k ., 2020)$. Adapun reformulasi kebijakan penanggulangan bencana khususnya pada saat prabencana untuk aspek kelembagaan yaitu perkuatan kebijakan pengarusutamaan (mainstreaming) pengurangan risiko bencana ke seluruh lapisan masyarakat, melalui komunikasi, informasi, dan edukasi (KIE) serta partisipasi dan kolaborasi seluruh pihak. Kolaborasi berbagai pihak terbukti dapat mengefektifkan upaya penanggulangan bencana (Suartini $d k k$., 2015), (Munir, 2017), (Hakam, 2018), (Tyas $d k k ., 2020)$.

Pendanaan (budjeting) pada tahap prabencana masih menjadi pekerjaan besar. Dana kontijensi yang tersebar di Kementerian/Lembaga maupun diberbagai stakeholder masih belum optimal jika dari segi outcome maupun impactnya. Pembelajaran dari bencana besar seperti Tsunami Aceh dan Gempa Yogyakarta berdampak pada Gross domestic product (GDP). Pada saat Tsunami Aceh (2004), maka 3\% GDP secara nasional menghilang, sementara Gempa
Yogyakarta (2006) kehilang 30\% GPD dari Provinsi DIY (Samad $d k k$., 2020). Hal ini tentunya menjadi perhatian dalam hal masih minimnya pendanaan yang bersifat investasi pengurangan risiko bencana. Kedepan, reformulasi kebijakan pendanaan yang diusulkan untuk tahap prabencana yaituperkuatan kebijakan pendanaan yang bersifat pro-investasi berbasis risiko (seperti dana kontijensi maupun asuransi kebencanaan). Investasi pengurangan risiko bencana untuk pendanaan pembangunan yang bersifat kesiapsiagaan, mitigasi (struktural dan non struktural) maupun investasi lainnya yang bersifat pengurangan risiko bencana.

\section{Reformulasi Kebijakan pada Tahap Tanggap Darurat}

Dalam UU 24 tahun 2007 tentang penanggulangan bencana, penyelenggaraan penanggulangan bencana pada saat tanggap darurat meliputi: (1) pengkajian secara cepat dan tepat terhadap lokasi, kerusakan, dan sumber daya; (2) penentuan status keadaan darurat bencana; (3) penyelamatan dan evakuasi masyarakat terkena bencana; (4) pemenuhan kebutuhan dasar; (5) pelindungan terhadap kelompok rentan; dan (6) pemulihan dengan segera prasarana dan sarana vital.

Salah satu tantangan dari kerangka regulasi yang ada saat ini, masih terdapat gap, legislasi yang belum disusun sebagaimana amanat UU 24 tahun 2007 tentang penanggulangan bencana, yaitu aturan turunan berupa Peraturan Presiden terkait Status dan Tingkatan Bencana yang belum terealisasi. Hal ini menjadi penting mengingat tantangan luas wilayah Indonesia yang berisiko tinggi terhadap bencana dan keterbatasan sumberdaya (resources), sehingga perlu manajemen yang lebih efektif dan efisien. Usulan reformulasi kebijakan terkait kerangka regulasi atau legislasi, yaitu perlu disusun aturan turunan terkait status dan tingkatan 
bencana, serta peran dan tanggung jawab pada saat tanggap darurat.

Perencanaan pada saat tanggap darurat masih sangat minim. Sampai dengan saat ini, belum tersedianya perencanaan atau analisis kebutuhan (need asesstment) untuk Penanganan Darurat Bencana (PDB) yang fungsinya untuk mempermudah operasi darurat (seperti kajian kebutuhan logistik untuk penyintas, data informasi sarana logistik yang dapat digunakan, moda transportasi, informasi akses, dan sebagainya yang menjadi ruang lingkup penanganan darurat bencana). Sejalan dengan hal tersebut, studi yang dilakukan di Jawa Timur, seperti di Kabupaten Kediri yaitu dilakukan oleh Fitrianto (2020) yang mengemukakan bahwa Belum tersedianya rencana kontijensi bencana letusan Gunung Kelud di BPBD setempat, serta belum adanya berbagai Standar Operasional Prosedur (SOP) Pemberian Bantuan Korban Bencana yang disebabkan oleh bencana kegagalan Konstruksi; SOP Pengendalian bantuan; SOP tentang relawan dalam negeri dan luar negeri (Fitrianto, 2020). Reformulasi kebijakan perencanaan pada saat tanggap darurat yaitu menyusun rencana kontijensi dan rencana operasi (yang dapat segera diaktivasi) dan dapat langsung digunakan secara operasional kedaruratan, utamanya pada wilayah yang berisiko tinggi bencana.

Dalam hal kelembagaan penanggulangan bencana pada saat tanggap darurat, berdasarkan hasil evaluasi yaitu masih terdapat multi interpretasi terhadap aktivitas keposkoan penanganan darurat bencana, utamanya pembagian peran antara pusat, provinsi, dan kabupaten. Hambatan dan tantangan kelembagaan keposkoan pada saat tanggap darurat yaitu ketidakjelasan personil hingga belum jelasnya pedoman (blue print) serta standar operasional prosedur (SOP) pada saat tanggap darurat (Suarjat, 2017). Pentingnya juga penetrasi kelembagaan dengan melibatkan masyarakat pada saat keadaan darurat bencana (Nasution, 2021). Reformulasi penguatan kebijakan penanggulangan bencana pada saat tanggap darurat, khususnya untuk kelembagaaan yang diusulkan yaitu perkuat kapasitas Sumber Daya Manusia (SDM) dan kelembagaan Sistem Komando Penanganan Darurat Bencana (SKPDB) seluruh pihak (stakeholder) yang terlibat dalam tahap atau fase tanggap darurat. Unsur pentahelix, yaitu pemerintah, akademisi, dunia usaha, media, dan masyarakat berkolaborasi sesuai perannya masing-masing.

Isu pendanaan pada tahap tanggap darurat merupakan salah satu isu yang sering muncul di berbagai daerah. Hal ini juga disampaikan oleh (Nugraha $d k k$., 2020), yaitu menyampaikan kondisi pendanaan pada saat kebakaran hutan dan lahan yang minim sehingga penanganan kedarurat bencana terhambat dan tidak optimal (Nugraha $d k k$., 2020). Minimnya politik anggaran dan keberpihakan Pemerintah Daerah (Pemda) dalam alokasi Belanja Tak Terduga (BTT) juga menjadi kendala di berbagai daerah (Silmi, Nur dan Purwanti, 2019). Dilain sisi, pendanaan melalui BTT dianggap tidak fleksibel dan rawan terhadap penyimpangan. Usulan reformulasi kebijakan pendanaan pada saat tanggap darurat yaitu berupa perkuatan kebijakan pendanaan, salah satunya skema BTT dengan Permendagri serta aturan yang operasional dan fleksibel, sehingga Pemda aman (tidak takut pada saat implementasi BTT).

\section{Reformulasi Kebijakan pada Tahap Pascabencana}

Dalam UU 24 tahun 2007 tentang penanggulangan bencana, penyelenggaraan penanggulangan bencana pada pascabencana meliputi: (1) rehabilitasi; dan (2) rekonstruksi. Adapun rehabilitasi meliputi: (1) perbaikan lingkungan daerah bencana; (2) perbaikan prasarana dan sarana umum; 
(3) pemberian bantuan perbaikan rumah masyarakat; (4)pemulihan sosial psikologis; (5) pelayanan kesehatan; (6) rekonsiliasi dan resolusi konflik; (7) pemulihan sosial ekonomi budaya; (8) pemulihan keamanan dan ketertiban; (9) pemulihan fungsi pemerintahan; dan (10) pemulihan fungsi pelayanan publik. Sementara rekonstruksi meliputi: (1) pembangunan kembali prasarana dan sarana; (2) pembangunan kembali sarana sosial masyarakat; (3) pembangkitan kembali kehidupan sosial budaya masyarakat; (4) penerapan rancang bangun yang tepat dan penggunaan peralatan yang lebih baik dan tahan bencana; (5) partisipasi dan peran serta lembaga dan organisasi kemasyarakatan, dunia usaha, dan masyarakat; (6) peningkatan kondisi sosial, ekonomi, dan budaya; (7) peningkatan fungsi pelayanan publik; dan (8) peningkatan pelayanan utama dalam masyarakat.

Berbagai legislasi atau regulasi pada tahapan pascabencana dari tingkat Peraturan Pemerintah (PP) hingga Peraturan BNPB telah ada, namun belum mengatur peran multipihak pada tahap pascabencana secara mendetail. Secara legislasi, telah ada Peraturan BNPB Nomor 5 tahun 2017 terkait Rencana Rehabilitasi dan Rekonstruksi Pascabencana (R3P). Namun demikian, legislasi tersebut belum mengatur rinci peran multipihak dan cenderung BNPB selaku pelaksana utama rehabilitasi dan rekonstuksi pascabencana. Sehingga kedepan, perlu adanya perkuatan refomulasi kebijakan berupa regulasi yang mengatur peran multi pihak secara mendetail pada tahapan pascabencana. BNPB maupun BPBD dalam hal tersebut berperan sebagai koordinator, sementara untuk implementasi diserahkan kepada masing-masing sektor.

Berdasarkan evaluasi, aspek perencanaan pada tahap pascabencana masih perlu dioptimlakan. Dokimen perencanaan berupa Rencana Rehabilitasi dan
Rekonstruksi Pascabencana (R3P) masih bersifat indikasi kebutuhan pascabencana, namun belum siap diimplementasikan secara langsung dalam bentuk kegiatan. Hal tersebut disampaikan dalam penelitian Sutrisna (2020), bahwa tidak seluruh sektor berkomitmen dalam implementasi kebijakan pascabencana yang tertuang sesuai dokumen rencana rehabilitasi dan rekonstruksi pascabencana(Sutrisna, 2020). Adapun usulan re-formulasi kebijakan penanggulangan bencana untuk aspek perencanaan pada tahap pascabencana, yaitu perlunya rencana pemulihan yang lebih operasional (bukan bersifat indikasi program), tetapi rencana aksi (action plan) dengan pendekatan berbasis perencanaan ruang (spatial planning) dan berprinsip build back better, safer and sustainable.

Berdasarkan evaluasi, aspek kelembagaan pada tahap pascabencana, yaitu belum seluruh sektor komitmen dalam hal implementasi kebijakan pada saat pascabencana. Hal ini umumnya karena keterbatasan sumberdaya (pendanaan, waktu dan SDM) (Sutrisna, 2020), (Shalih dan Koestoer, 2019). Adapun usulan reformulasi kebijakan perlunya perkuatan kelembagaan BNPB dan BPBD sebagai koordinator utama pada saat rehabilitasi dan rekonstruksi pascabencana.

Dalam tahapan pascabencana, maka aspek pendanaan (budjeting) berperan sangat penting, yaitu merupakan faktor kunci keberhasilan pembangunan kembali daerah terdampak bencana (Cempaka dkk., 2021), (Shalih dan Koestoer, 2019). Sama halnya kejadian pascabencana di Kabupaten Trenggalek Jawa Timur. Alokasi pendanaan yang memadai serta proses dukungan Coorporate Social Responsibility (CSR) Bank Jawa Timur mempercepat proses rehabilitasi dan rekonstruksi pascabencana (Wijayanto dkk., 2020). Adapun usulan reformulasi kebijakan pendanaan pada tahap pascabencana, yaitu perlunya alternatif pendanaan rehabilitasi 
dan rekonstruksi pascabencana, antara lain dalam bentuk: pooling fund; asuransi bencana; serta instrumen disaster risk financing lainnya.

\section{SIMPULAN}

Dari pembahasan diatas, bahwa dalam Undang-Undang Nomor 24 Tahun 2007 tentang Penanggulangan Bencana telah digambarkan suatu Sistem Penanggulangan Bencana yang bersifat Nasional dan merupakan satu kesatuan sistem penyelenggaraan penanggulangan bencana yang terintegrasi meliputi aspek legislasiregulasi, perencanaan, kelembagaan dan pendanaan, maupun penyelenggaraan penggulangan bencana. Adapun reformulasi kebijakan penanggulangan bencana yang perlu diperkuat untuk sistem pe-nanggulangan bencana sebagai berikut: (1) Prabencana, (2) Tanggap Darurat, dan (3) Pascabencana. Reformulasi kebijakan penanggulangan bencana yang diusulkan sepenuhnya harus bersifat: (1) melindungi segenap bangsa Indonesia dan seluruh tumpah darah Indonesia (seperti usulan kebijakan pendanaan yang memadai untuk setiap tahapan mulai dari pra, saat, dan pasca); (2) memajukan kesejahteraan umum (seperti usulan reformulasi kebijakan pascabencana yang berprinsip build back better, safer and sustainable); (3) mencerdaskan kehidupan bangsa (seperti usulan reformulasi kebijakan perkuatan kebijakan pengarusutamaan atau mainstreaming pengurangan risiko bencana ke seluruh lapisan masyarakat, melalui komunikasi, edukasi dan informasi); (4) ikut melaksanakan ketertiban dunia berdasarkan kemerdekaan, perdamaian abadi dan keadilan sosial (seperti usulan reformulasi kebijakan melakukan kerjasama, baik dalam dan luar negeri untuk kebencanaan, dimana bencana sebagai urusan bersama). Usulan reformulasi kebijakan penanggulangan bencana dimaksud, telah sejalan dengan konstitusi negara Indonesia, yaitu Undang-Undang Dasar 1945.

\section{DAFTAR PUSTAKA}

Ambo dan Sulandari, N. W. (2008). Kinerja Badan Penanggulangan Bencana Daerah dalam Menangani Prabencana Gunung Slamet di Desa Kutabawa Kecamatan Karangrejo Kabupaten Purbalingga Jawa Tengah. Andhini. 3-28.

Cempaka, S., Ardiansyah, A. R., Rahmawati, L., \& Yunia, M. (2021). Kebijakan Pemerintah dalam Penanggulangan Bencana di Indonesia (Government Policy regarding Disaster Management in Indonesia). 1(1), 35-45.

Craft, J., \& Howlett, M. (2012). Policy formulation, governance shifts and policy influence: Llocation and content in policy advisory systems. Journal of Public Policy, 32(2), 79-98. https://doi.org/10.1017/ S0143814X12000049.

Creswell, J. W. (2013). Qualitative inquiry and research design. Thousand Oaks. Thousand Oaks: SAGE.

Dunn, W. N. (1994). Public Policy Analysis: An Introduction. Prentice Hall.

Fitrianto, M. R. (2020). Evaluasi Kebijakan Penanggulangan Bencana (Studi pada BPBD Kabupaten Kediri). Jurnal Ilmiah Administrasi Publik, 006(02), 197-201. https://doi.org/10.21776/ ub.jiap.2020.006.02.4. 
Hadi, S. (2020). Pengurangan Risiko Pandemi Covid-19 Secara Partisipatif: Suatu Tinjauan Ketahanan Nasional terhadap Bencana. Jurnal Perencanaan Pembangunan: The Indonesian Journal of Development Planning, 4(2), 177-190. https://doi. org/10.36574/jpp.v4i2.109.

Hakam, A. M. (2018). Evaluasi Penanganan Banjir Rob di Kota Semarang oleh Pemer intah Kota Semarang ". Journal of Politic and Government Studies, 8(1), 281-290. Retrieved from https://ejournal3.undip. ac.id/index.php/jpgs/article/ view/22798.

Hartono, D., Khoirudin Apriyadi, R., Winugroho, T., Aprilyanto, A., Hadi Sumantri, S., Wilopo, W., \& Surya Islami, H. (2021). Analisis Sejarah, Dampak, dan Penanggulangan Bencana Gempa Bumi pada Saat Pandemi Covid-19 di Sulawesi Barat. PENDIPA Journal of Science Education, 5(2), 218-224. https://doi.org/10.33369/ pendipa.5.2.218-224.

Hayaturrahmi, R., \& Husna, C. (2018). Kesiapsiagaan Sumber Daya dan Kerja Sama dalam Sistem Penanggulangan Gawat Darurat Terpadu pada Manajemen Bencana. JIM Fkep, III(3), 19-27.

Hogan, J., \& Howlett, M. (2015). Policy paradigms in theory and practice : discourses, ideas and anomalies in public policy dynamics. Palgrave Macmillan.

Jachock, W. W. (2016). Graham T. Allison 's Three Dimensions of Decision -Making Revisited: A Case Study of Rice Price Policy in Thailand. 513-529.
Kelly,L., \&Booth, C. (2013).Administrative Behavior. Dictionary of Strategy: Strategic Management A-Z. https:// doi.org/10.4135/9781452229805. n17.

Kodar, M. S. (2020). Nusantara (Jurnal Ilmu Pengetahuan Sosial ). Nusantara: Jurnal Ilmu Pengetahuan Sosial, 7(2), 408-420.

Kristian, R. (2018). Faktor-Faktor Penghambat Implementasi Kebijakan Penanggulangan Bencana Erupsi Gunung Sinabung. Talenta Conference Series: Local Wisdom, Social, and Arts (LWSA), 1(1), 099-103. https://doi. org/10.32734/lwsa.v1i1.149.

Luh, N., Astariyani, G., \& Sudiarawan, K. A. (2021). Evaluation Of Regional Policy Arrangements in The Time of The Covid-19 Pandemic in Denpasar City. 8 (April), 65-71.

Maarif, S. (2012). Pikiran dan Gagasan Penanggulangan Bencana di Indonesia. In Bintek Manajemen Penyusunan Peta Rawan Bencana.

Maarif, S. (2013). Meningkatkan Kapasitas Masyarakat Dalam Mengatasi Risiko Bencana Kekeringan. Jurnal Sains Dan Teknologi Indonesia, 13(2), 65-73. https:// doi.org/10.29122/jsti.v13i2.886.

Maarif Syamsul,Pramono Rudy , Kinseng Rilus A., S. E. (2012). Ancaman Bencana Alam (Studi Kasus Ancaman Bencana Gunung Merapi). Jurnal Dialog Penanggulangan Bencana, 3, $1-13$. 
Makmur, M. T., \& Hadi, S. (2020). Strategi Pemulihan Perekonomian Terdampak Covid-19 Melalui Perencanaan Pembangunan Sumber Daya Manusia Unggul. 1(1), 117-126.

Muhyiddin, \& Hadi, S. (2020). Sinergi Prioritas Program Kerja Pemerintah 2020-2024 dengan Kerangka Ketahanan Nasional dalam Penanganan Covid-19. Media Perencana, 1(1), 127-136. Retrieved from https://mediaperencana. perencanapembangunan.or.id/ index.php/mmp/article/view/8/8.

Munir, M. (2017). Evaluasi Pelaksanaan Program Desa Tangguh Bencana di Kabupaten Kendal Tahun 2016. Journal of Politic and Government Studies, 6 (3), 421-430. Retrieved from https://ejournal3.undip. ac.id/index.php/jpgs/article/ view/16746/16082.

Nasution, Z. . (2021). Evaluasi Kebijakan Penanganan Covid-19 di Kota Surabaya: Studi Kasus Kebijakan PSBB. Ganaya: Jurnal Ilmu Sosial Dan Humaniora, 4(1), 98-115.

Nugraha, S. A., Febriyanti, D., \& Kencana, N. (2020). Evaluasi Penanggulangan Bencana Kebakaran di Kota Palembang (Studi Kasus Pada Badan Penanggulangan Bencana Daerah Provinsi Sumatera Selatan Tahun 2016-2018). Jurnal Pemerintahan Dan Politik, 5(2). https://doi. org/10.36982/jpg.v5i2.1033.

Nugroho, R. (2014). Public Policy. Jakarta: Elex Media Komputindo (Gramedia).

Nugroho, R. (2015). Policy Making. Jakarta: PT Elex Multimedia.
Patton, C. V., \& Sawicki, D. S. (1993). Basic Methods of Policy Analysis and Planning. Prentice Hall.

Pearson. (2013). Politics and the Policymaking Process. Pearson: Policy and the Policymaking Process, 12-26. Retrieved from www.mysocialworklab.com.

Samad, A., Erdiansyah, E., \& Wulandari, R. (2020). Evaluasi Kebijakan Pemerintah Pasca Bencana (Studi Kasus Bencana di Sulawesi Tengah). Publik (Jurnal Ilmu Administrasi), 9(1), 15. https://doi. org/10.31314/pjia.9.1.15-24.2020.

Shalih, O. (2019). Membangun Ketahanan (Resiliensi) Bencana pada $\mathrm{Ka}$ wasan Pariwisata (Studi Kasus: Kabupaten Pandeglang Pasca Tsunami Selat Sunda 2018). https:// doi.org/10.31227/osf.io/v3yxs.

Shalih, O., \& Koestoer, R. (2019). Pola Pendanaan Rehabilitasi dan Rekonstruksi Pascabencana. Majalah Geospasial, 17 (2). https://doi. org/10.17605/OSF.IO/3X5YE.

Shalih, O., Setiadi, H., Nurlambang, T., \& Sumadio, W. (2020). Toward a community resilience framework for disaster risk management. a case study: Landslide Cisolok in Sukabumi 2018 and Sunda Strait Tsunami in Pandeglang 2018. E3S Web of Conferences, 156. https://doi.org/10.1051/ e3sconf/202015601011.

Silmi, N. R., Nur, T., \& Purwanti, D. (2019). Implementasi Kebijakan Penanggulangan Bencana Daerah di Kota Sukabumi. JOPPAS: Journal of Public Policy and Administration Silampar, 1(1), 30-40. 
Strauss dan Corbin J. (2003). Dasar-Dasar Penelitian Kualitatif : Tatalangkah dan Tekni-teknik Teorisasi Data. Yogyakarta: Pustaka Pelajar.

Suarjat, J. (2017). Evaluation The Effectivenness of Disaster Rapid Response Unit. 8 (1).

Suartini, K., Noak, P. A., \& Winaya, I. K. (2015). Evaluasi Kinerja Badan Penanggulangan Bencana Daerah (Bpbd) Kabupaten Badung dalam Bidang Pencegahan dan Kesiapsiagaan Bencana Tahun 2014. Citizen Charter. Retrieved from https://www.neliti.com/ publications/28609/evaluasikinerja-badan-penanggulanganbencana-daerah-bpbd-kabupatenbadung-dalam.

Sutrisna, E. (2020). Evaluasi implementasi kebijakan penanggulangan bencana hidrometereologi bidang kesehatan di kabupaten aceh utara. 4, 176-186.
Tyas, R. A., Pujianto, P., \& Suyanta, S. (2020). Evaluasi manajemen Program Sekolah Siaga Bencana (SSB). Jurnal Akuntabilitas Manajemen Pendidikan, 8(1), 1023. https://doi.org/10.21831/jamp. v8i1.28850.

Wijayanto, M., Muchsin, S., \& Hayat. (2020). Evaluasi Kebijakan Bencana Alam (Studi Pengaruh Kegiatan Penambangan Pasir Terhadap Kondisi Sosial Ekonomi Masyarakat Studi di Kabupaten Lumajang) Muchamad Arif Wijayanto $^{1}$, Slamet Muchsin ${ }^{2}$ dan Hayat $^{3}$ Program Studi Administrasi Publik, Fakultas Ilmu Ad. Jurnal Respon Publik, 14(4), 36-39. 
Tabel 1. Evaluasi dan Reformulasi Kebijakan Penanggulangan Bencana di Indonesia

\begin{tabular}{|c|c|c|c|}
\hline Tahapan & Aspek & Evaluasi Kebijakan & Reformulasi Kebijakan \\
\hline \multirow[t]{4}{*}{ Prabencana } & $\begin{array}{l}\text { legislasi } \\
\text { (regulation) }\end{array}$ & $\begin{array}{l}\text { Belum seluruhnya regulasi yang } \\
\text { disusun adaptif dengan upaya } \\
\text { pengurangan risiko bencana } \\
\text { (peka terhadap aspek kebenca- } \\
\text { naan) }\end{array}$ & $\begin{array}{l}\text { Perkuatan kebijakan pengarusu- } \\
\text { tamaan (mainstreaming) penguran- } \\
\text { gan risiko bencana ke dalam regu- } \\
\text { lasi yang disusun, utamanya terkait } \\
\text { pembangunan di pusat dan daerah } \\
\text { (RPJMN/D, RKP/D, RTR/RTRW/ } \\
\text { RDTR, Amdal, dan sebagainya) }\end{array}$ \\
\hline & $\begin{array}{l}\text { perencanaan } \\
\text { (planning) }\end{array}$ & $\begin{array}{l}\text { belum sepenuhnya perencanaan } \\
\text { pembangunan di daerah memas- } \\
\text { ukan aspek kebencanaan }\end{array}$ & $\begin{array}{l}\text { perkuatan kebijakan pengarusu- } \\
\text { tamaan (mainstreaming) pengu- } \\
\text { rangan risiko bencana ke dalam } \\
\text { rencana pembangunan di pusat } \\
\text { hingga ke daerah }\end{array}$ \\
\hline & $\begin{array}{l}\text { kelembagaan } \\
\text { (institutional) }\end{array}$ & $\begin{array}{l}\text { belum sepenuhnya mindset } \\
\text { pengurangan risiko bencana } \\
\text { masuk ke dalam sendi kehidu- } \\
\text { pan (paradima lama: reaktif jika } \\
\text { terjadi bencana, belum bertindak } \\
\text { proaktif/mitigatif) }\end{array}$ & $\begin{array}{l}\text { perkuatan kebijakan pengarusu- } \\
\text { tamaan (mainstreaming) pengu- } \\
\text { rangan risiko bencana ke seluruh } \\
\text { lapisan masyarakat, melalui komu- } \\
\text { nikasi, edukasi dan informasi }\end{array}$ \\
\hline & $\begin{array}{l}\text { pendanaan } \\
\text { (budjeting) }\end{array}$ & $\begin{array}{l}\text { masih minimnya pendanaan } \\
\text { yang bersifat investasi pengu- } \\
\text { rangan risiko bencana }\end{array}$ & $\begin{array}{l}\text { perkuatan kebijakan pendanaan } \\
\text { yang bersifat pro investasi risiko } \\
\text { (seperti dana kontijensi maupun } \\
\text { asuransi kebencanaan). Investasi } \\
\text { pengurangan risiko bencana untuk } \\
\text { pendanaan pembangunan yang } \\
\text { bersifat mitigasi (struktural dan non } \\
\text { struktural) }\end{array}$ \\
\hline \multirow[t]{4}{*}{$\begin{array}{l}\text { saat tanggap } \\
\text { darurat }\end{array}$} & $\begin{array}{l}\text { legislasi } \\
\text { (regulation) }\end{array}$ & $\begin{array}{l}\text { amanat UU 24/2007 untuk } \\
\text { menyusun aturan turunan terkait } \\
\text { status dan tingkatan bencana } \\
\text { belum disusun }\end{array}$ & $\begin{array}{l}\text { perlu disusun aturan turunan terkait } \\
\text { status dan tingkatan bencana, serta } \\
\text { peran dan tanggung jawab pada saat } \\
\text { tanggap darurat }\end{array}$ \\
\hline & $\begin{array}{l}\text { perencanaan } \\
\text { (planning) }\end{array}$ & $\begin{array}{l}\text { belum tersedianya perencanaan/ } \\
\text { analisis kebutuhan saat PDB } \\
\text { yang mempermudah operasi } \\
\text { darurat (kajian kebutuhan logis- } \\
\text { tic untuk penyintas, data infor- } \\
\text { masi sarana logistik yang dapat } \\
\text { digunakan, moda transportasi, } \\
\text { informasi akses, dsbg) }\end{array}$ & $\begin{array}{l}\text { menyusun rencana kontijensi dan } \\
\text { rencana operasi (yang dapat segera } \\
\text { diaktivasi) yang dapat langsung } \\
\text { digunakan secara operasional ke- } \\
\text { daruratan }\end{array}$ \\
\hline & $\begin{array}{l}\text { kelembagaan } \\
\text { (institutional) }\end{array}$ & $\begin{array}{l}\text { masih multiinterpretasi terhadap } \\
\text { aktivitas keposkoan penanga- } \\
\text { nan darurat bencana, utamanya } \\
\text { pembagian peran antara pusat, } \\
\text { provinsi, dan kabupaten }\end{array}$ & $\begin{array}{l}\text { perkuat kapasitas SDM dan kelem- } \\
\text { bagaan sistem komando penan- } \\
\text { ganan darurat bencana (SKPDB) } \\
\text { seluruh stakeholder yang terlibat } \\
\text { dalam penangananan darurat (saat } \\
\text { tanggap darurat) }\end{array}$ \\
\hline & $\begin{array}{l}\text { pendanaan } \\
\text { (budjeting) }\end{array}$ & $\begin{array}{l}\text { kurangnya keberpihakan pemda } \\
\text { dalam pendanaan operasi PDB } \\
\text { (pendanaan BTT yang tidak } \\
\text { fleksibel); }\end{array}$ & $\begin{array}{l}\text { perkuatan kebijakan pendanaan, } \\
\text { salah satunya skema BTT dengan } \\
\text { Permendagri serta aturan yang } \\
\text { operasional dan fleksibel, sehingga } \\
\text { Pemda aman (tidak takut pada saat } \\
\text { implementasi BTT) }\end{array}$ \\
\hline
\end{tabular}




\begin{tabular}{|c|c|c|c|}
\hline Tahapan & Aspek & Evaluasi Kebijakan & Reformulasi Kebijakan \\
\hline \multirow[t]{4}{*}{ Pascabencana } & $\begin{array}{l}\text { legislasi } \\
\text { (regulation) }\end{array}$ & $\begin{array}{l}\text { berbagai aturan penyelenggaraan } \\
\text { dari tingkat Peraturan Pemerin- } \\
\text { tah (PP) hingga Peraturan BNPB } \\
\text { telah ada, namun belum menga- } \\
\text { tur peran multi pihak pada tahap } \\
\text { pascabencana secara mendetail }\end{array}$ & $\begin{array}{l}\text { perlunya legislasi/regulasi yang } \\
\text { mengatur peran multi pihak secara } \\
\text { mendetail pada tahapan pascaben- } \\
\text { cana }\end{array}$ \\
\hline & $\begin{array}{l}\text { perencanaan } \\
\text { (planning) }\end{array}$ & $\begin{array}{l}\text { rencana rehabilitasi dan rekon- } \\
\text { struksi pascabencana (R3P) } \\
\text { masih bersifat indikasi kebutu- } \\
\text { han pascabencana, namun belum } \\
\text { siap diimplementasikan secara } \\
\text { langsung dalam bentuk kegiatan }\end{array}$ & $\begin{array}{l}\text { perlunya rencana pemulihan yang } \\
\text { lebih operasional (bukan bersifat } \\
\text { indikasi program), tetapi rencana } \\
\text { aksi (action plan) dengan berbasis } \\
\text { spatial planning berprinsip build } \\
\text { back better, safer and sustainable. }\end{array}$ \\
\hline & $\begin{array}{l}\text { kelembagaan } \\
\text { (institutional) }\end{array}$ & $\begin{array}{l}\text { koordinasi pada pascabencana } \\
\text { belum terlalu efektif untuk } \\
\text { mengkoordinasikan seluruh } \\
\text { elemen bangsa maupun sumber- } \\
\text { daya yang tersedia }\end{array}$ & $\begin{array}{l}\text { perlunya perkuatan kelembagaan } \\
\text { BNPB dan BPBD sebagai koordina- } \\
\text { tor utama pada saat rehabilitasi dan } \\
\text { rekonstruksi pascabencana }\end{array}$ \\
\hline & $\begin{array}{l}\text { pendanaan } \\
\text { (budjeting) }\end{array}$ & $\begin{array}{l}\text { kebutuhan pendanaan pemuli- } \\
\text { han pascabencana lebih besar } \\
\text { dibandingkan resources APBN/ } \\
\text { APBD (cenderung tidak mema- } \\
\text { dai). }\end{array}$ & $\begin{array}{l}\text { perlunya alternatif pendanaan reha- } \\
\text { bilitasi dan rekonstruksi pascaben- } \\
\text { cana, a.l: } \\
\text { pooling fund } \\
\text { asuransi bencana dan instrumen } \\
\text { disaster risk financing lainnya. }\end{array}$ \\
\hline
\end{tabular}

Sumber: Hasil Analisis, 2021 